\title{
Article \\ High Q Dielectric Titanium Tellurite Thick Films on Alumina Substrates for High Frequency Telecommunications
}

\author{
Xinming Su ${ }^{1}$, Alexander Tkach ${ }^{1}{ }^{\mathbb{D}}$, Jerzy Krupka ${ }^{2}$ and Paula M. Vilarinho ${ }^{1, *}$ \\ 1 Department of Materials and Ceramic Engineering, CICECO-Aveiro Institute of Materials, \\ University of Aveiro, Campus de Santiago, 3810-193 Aveiro, Portugal; xinming@ua.pt (X.S.); \\ atkach@ua.pt (A.T.) \\ 2 Institute of Microelectronics and Optoelectronics, Warsaw University of Technology, 00662 Warsaw, Poland; \\ j.krupka@imio.pw.edu.pl \\ * Correspondence: paula.vilarinho@ua.pt
}

check for updates

Citation: Su, X.; Tkach, A.; Krupka, J.; Vilarinho, P.M. High Q Dielectric Titanium Tellurite Thick Films on Alumina Substrates for High Frequency Telecommunications. Materials 2022, 15, 467. https:// doi.org/10.3390/ma15020467

Academic Editor: Alain Walcarius

Received: 14 November 2021

Accepted: 5 January 2022

Published: 8 January 2022

Publisher's Note: MDPI stays neutral with regard to jurisdictional claims in published maps and institutional affiliations.

Copyright: (C) 2022 by the authors. Licensee MDPI, Basel, Switzerland. This article is an open access article distributed under the terms and conditions of the Creative Commons Attribution (CC BY) license (https:// creativecommons.org/licenses/by/ $4.0 /)$.

\begin{abstract}
The vital role of high-quality-factor (Q) high-frequency (f) dielectric resonators in the growing microwave telecommunication, satellite broadcasting and intelligent transport systems has long motivated the search for new, small size, and lightweight integrated components and packages, prepared by low cost and sustainable processes. One approach is replacing the currently used bulk ceramic dielectrics by thick films of low-sintering-temperature dielectrics fabricated by affordable processes. Here we demonstrate the fabrication of high-Q $\mathrm{TiTe}_{3} \mathrm{O}_{8}$ thick films directly on low loss $\mathrm{Al}_{2} \mathrm{O}_{3}$ substrates by electrophoretic deposition using sacrificial carbon layer. Nineteen-micrometrethick $\mathrm{TiTe}_{3} \mathrm{O}_{8}$ films on $\mathrm{Al}_{2} \mathrm{O}_{3}$ sintered at $700{ }^{\circ} \mathrm{C}$ are found to have a relative permittivity $\varepsilon_{\mathrm{r}}$ of 32 and $\mathrm{Q} \times \mathrm{f}>21,000 \mathrm{GHz}$. Being thus able to measure and provide for the first time the microwave dielectric properties of these films, our results suggest that $\mathrm{TiTe}_{3} \mathrm{O}_{8}$ films on $\mathrm{Al}_{2} \mathrm{O}_{3}$ substrates are suitable for microlayer microstrip array applications.
\end{abstract}

Keywords: $\mathrm{TiTe}_{3} \mathrm{O}_{8}$ thick films; electrophoretic deposition; alumina substrates; high-Q dielectrics; microwave properties

\section{Introduction}

Microwave dielectric materials play a vital role within a wide range of applications from terrestrial and satellite communication including software radio, Global Positioning Systems (GPS), and Direct Broadcast Satellite (DBS) television and environmental monitoring via satellites. The recent progress in microwave telecommunication, satellite broadcasting and intelligent transport systems (ITS) has resulted in an increasing demand for dielectric resonators (DRs), which are low loss ceramic pucks used mainly in wireless communication devices [1]. The key properties required for DR materials are high quality factor-frequency product $(Q \times f)$, high relative permittivity $\left(\varepsilon_{\mathrm{r}}\right)$ and near zero temperature coefficient of resonant frequency $\left(\tau_{\mathrm{f}}\right)$ or temperature coefficient of the relative permittivity $\left(\mathrm{TC} \varepsilon_{\mathrm{r}}\right)$. The relative permittivity determines the size of the electronic component, the temperature coefficient of resonant frequency establishes the frequency stability, and the loss tangent $(\tan \delta)$ or quality factor $(Q=1 / \tan \delta)$ controls the selectivity and performance of the device [2]. An optimal dielectric resonator that satisfies these three properties simultaneously is difficult to achieve solely in a particular material.

In order to meet the specifications of the current and future systems, improved or novel microwave components based on dedicated dielectric materials and new designs are required [3]. In addition, with the recent evolution in mobile phone and satellite communication systems, using microwaves as the carrier, the research and development in the field of device miniaturization is needed [4]. This fast-growing mobile/wireless communication industry is demanding small size and lightweight integrated components and packages at low cost. A method to meet these requirements, which are now under 
consideration by the community, is the replacement of the currently used bulk ceramic dielectrics by dielectric thick films [4,5].

Electrophoretic deposition (EPD) is one of the processing techniques of thick films. EPD is a colloidal process, in which charged particles dispersed in a stable suspension are driven by electric field to move towards oppositely charged electrodes to build up a particulate coating by deposition on one of the electrodes [3,6-10]. The main advantages of EPD are related to low cost, versatility and ability to coat conformal substrates. However, the utilization of insulating substrates required for low loss microwave applications raises difficulties for the preparation of continuous thick films by EPD, since to apply the electric field during the EPD process the substrate should be a conductor. Moreover, a high corrosion resistance in the EPD suspension and thermal stability are two major criteria that also limit drastically the use of conductive substrates in EPD [7]. This last aspect is of particular relevance when the thick film sintering temperature is high $\left(>1000^{\circ} \mathrm{C}\right)$, thus, restricting considerably the choice of electrodes to high temperature conductive oxides or noble metals, such as gold, platinum and palladium; both expensive alternatives.

There is, however, an approach developed for preparation of thick films by EPD on poorly conducting substrates, using a fugitive layer of graphite [11,12]. Moreover, Ystabilized zirconia (YSZ) films deposited this way on NiO-YSZ for fuel cell application were reported to be of improved quality. In our previous work, we adapted this approach to the more critical case of EPD films on insulating dielectric substrates (as alumina and glass) for electronic applications [13]. Thin sacrificial layers of conducting carbon were coated onto non-conducting alumina substrates to facilitate the conduction on the substrate surface. The carbon coating burns out during the sintering step, not interfering with the final product. To prove the concept, a layer of high $\mathrm{Q}$ ceramic powders of $\mathrm{BaNd}_{2} \mathrm{Ti}_{5} \mathrm{O}_{14}(\mathrm{BNT})$ was deposited by EPD on the top of the carbon coated alumina. One-hundred-micrometre-thick BNT films on $\mathrm{Al}_{2} \mathrm{O}_{3}$ substrates exhibited $\varepsilon_{\mathrm{r}}$ and $\mathrm{Q}$ of 146 and 1161 at about $10 \mathrm{GHz}$ when sintered at $1250{ }^{\circ} \mathrm{C} / 1 \mathrm{~h}$. Besides high $\mathrm{Q}$ values BNT films on alumina possess high thermal stability and, therefore, are potentially useful for high frequency applications [13]. To date this is the only report on EPD to produce high-Q dielectric thick films on alumina substrates. A limitation of the $\mathrm{BaO}-\mathrm{Nd}_{2} \mathrm{O}_{3}-\mathrm{TiO}_{2}$ system is the high sintering temperature $\left(>1300{ }^{\circ} \mathrm{C}\right)$ required to densify the ceramic bulk or thick layers.

Looking for low sintering temperature dielectrics with low dielectric losses and high capacitance stability tellurium-based systems stand out [14-29]. Ceramics of Te-based compounds sinter at temperatures under $900{ }^{\circ} \mathrm{C}[28,29]$ and exhibit low dielectric losses ( $\mathrm{Q} \times \mathrm{f}$ up to $66,000 \mathrm{GHz}$ for $\mathrm{Zn}_{2} \mathrm{Te}_{3} \mathrm{O}_{8}$ ceramics [23]) and dielectric permittivities ranging from 10.5 for $\mathrm{MgTe}_{2} \mathrm{O}_{5}$ [25] to 56 for $\mathrm{Bi}_{2} \mathrm{TeO}_{6}$ [16]. The temperature coefficient of resonant frequency varies from $-119 \mathrm{ppm} /{ }^{\circ} \mathrm{C}$ for $\mathrm{TeO}_{2}$ [16] to $+372 \mathrm{ppm} /{ }^{\circ} \mathrm{C}$ for $\mathrm{BaTiTe}_{3} \mathrm{O}_{9}$ [18]. For well sintered $\mathrm{TiTe}_{3} \mathrm{O}_{8}$ ceramics, $\varepsilon_{\mathrm{r}}$ is of 50 and $\mathrm{Q} \times \mathrm{f}$ is of $30,600 \mathrm{GHz}$ at a measurement frequency of $5 \mathrm{GHz}$ [15]. However, there is only one report on the preparation of telluriumbased thick films by EPD [30]. In this paper we reported the low-frequency dielectric properties of the $\mathrm{TiTe}_{3} \mathrm{O}_{8}$ films on platinized silicon [30]. Moreover, so far there is no report on the microwave characterization of Te-based thick films neither on their deposition on alumina.

In the present work, we have extended our previous approach of using sacrificial carbon layers for EPD on fully non-conducting substrates, to fabricate for the first time low sintering temperature high $\mathrm{Q}$ dielectric Te based thick films on insulator $\mathrm{Al}_{2} \mathrm{O}_{3}$ substrates. The dielectric characterization at high frequency suggests that these films are suitable for microlayer microstrip arrays.

\section{Materials and Methods}

The work here described comprises the following experimental steps: preparation of a stable suspension of $\mathrm{TiTe}_{3} \mathrm{O}_{8}$ particles synthesised by solid state reaction, carbon coating of the nonconducting $\mathrm{Al}_{2} \mathrm{O}_{3}$ substrates, EPD of green $\mathrm{TiTe}_{3} \mathrm{O}_{8}$ thick films on carbon coated 
$\mathrm{Al}_{2} \mathrm{O}_{3}$ substrates and their sintering, as well as electrical characterization of $\mathrm{TiTe}_{3} \mathrm{O}_{8}$ thick films on $\mathrm{Al}_{2} \mathrm{O}_{3}$ at microwave frequencies.

$\mathrm{TiTe}_{3} \mathrm{O}_{8}$ powders were synthesized from reagent-grade $\mathrm{TeO}_{2}(>99 \%$, Sigma-Aldrich, Saint Louis, MO, USA) and $\mathrm{TiO}_{2}(>99 \%$, Merck KGaA, Darmstadt, Germany) via a conventional solid-state-reaction method, as per [30]. The starting precursors were weighed according to the molar ratio of 3:1, ball mixed with ethanol and dried at $70{ }^{\circ} \mathrm{C}$ for $5 \mathrm{~h}$. The mixed powders were calcined at $620^{\circ} \mathrm{C}$ for $50 \mathrm{~h}$ and milled for $5 \mathrm{~h}$ in a planetary ball mill at $200 \mathrm{rpm}$ using Teflon pots and zirconia balls. Milled $\mathrm{TiTe}_{3} \mathrm{O}_{8}$ powders with particle size below $10 \mu \mathrm{m}$ were ultrasonically dispersed in acetone ( $>99.5 \%$, Panreac Química SLU, Castellar del Vallès, Spain) with a concentration of $10 \mathrm{~g} / 1$. Triethanolamine (TEA) ( $>99 \%$, Merck KGaA, Darmstadt, Germany) was added as a suspension stabilizer to favour the EPD process [31]. The addition of TEA increased considerably the zeta potential of the suspension to $46.5 \mathrm{mV}$ at $\mathrm{pH}$ of 8.1 that guaranteed the fabrication of crack free and homogeneous films. The suspensions were magnetically stirred for $5 \mathrm{~h}$ at room temperature. The stability of the suspensions was analysed by transmittance of the UV light (UV-2101/3101PC, Shimadzu Corporation, Kyoto, Japan), particle size distribution and zeta potential techniques (Malvern Zeta sizer Nano ZS, Malvern, Worcestershire, UK).

Non-conducting alumina substrates were coated with a sacrificial conducting carbon film that acts as a temporary electrode being burned at high sintering temperatures without leaving any residual contaminations, as mentioned before. Following our previous work [13], a radio frequency (RF) magnetron sputtering (CRIOLAB, Porto, Portugal) was used to perform the deposition of the carbon layer from the corresponding target (purity $>99.9 \%$, Sofacel Inc., Madrid, Spain) of $55 \mathrm{~mm}$ in diameter and $3 \mathrm{~mm}$ in thickness on $25.4 \times 25.4 \times 0.0254 \mathrm{~mm}^{3}$ polycrystalline $\mathrm{Al}_{2} \mathrm{O}_{3}$ substrates $(99.6 \%$, Coors Ceramics U.K., Glenrothes, Fife, Scotland, UK, with the remaining $0.4 \mathrm{wt}$. \% assumed to be a silicate based sintering aid). The carbon coatings were prepared at a substrate-magnetron distance of $120 \mathrm{~mm}$ under Ar pressure of $5.8 \times 10^{-3}$ mbar, with a magnetron current of $0.3 \mathrm{~A}$ and a substrate bias of $470 \mathrm{~V}$. The thickness of the carbon layer was controlled by the deposition time.

The carbon coated $\mathrm{Al}_{2} \mathrm{O}_{3}$ was employed as a substrate for the deposition of $\mathrm{TiTe}_{3} \mathrm{O}_{8}$ films and stainless steel was chosen as the counterpart electrode. EPD was carried out for $3 \mathrm{~min}$ under a dc voltage of $100 \mathrm{~V}$ from the voltage supply (Glassman High Voltage Inc., High Bridge, NJ, USA). The obtained films were dried for more than $24 \mathrm{~h}$ at room temperature and then sintered from $680^{\circ} \mathrm{C}$ to $720^{\circ} \mathrm{C}$ for $5 \mathrm{~h}$ in a closed alumina crucible together with $\mathrm{TeO}_{2}$ powders, to avoid Te volatilization. The use of $\mathrm{TeO}_{2}$ powder was reported to increase the partial pressure of $\mathrm{TeO}_{2}$ and to suppress the evaporation from $\mathrm{TiTe}_{3} \mathrm{O}_{8}[30]$.

The crystallographic structure and phase content of $\mathrm{TiTe}_{3} \mathrm{O}_{8}$ films were analysed by $X$-ray diffraction (XRD, PANalytical X'Pert Pro diffractometer, Philips, Amsterdam, The Netherlands, $\mathrm{Cu}-\mathrm{K} \alpha$ radiation, $45 \mathrm{kV}$ and $40 \mathrm{~mA}$ ), used from $10^{\circ}$ to $80^{\circ} 2 \theta$ with a step size of $0.025^{\circ}$. The microstructure of the thick films was observed using scanning electron microscopy (SEM, SU-70, Hitachi, Tokyo, Japan) coupled with energy-dispersive X-ray spectroscopy (EDS, QUANTAX 400, Bruker, Billerica, MA, USA). The thickness of green and sintered films was evaluated by a micrometre and SEM.

For microwave frequency characterization the split post dielectric resonator (SPDR) method was used [32]. Thus, $\varepsilon_{\mathrm{r}}$ and quality factor $(\mathrm{Q})$ were determined at $\sim 20 \mathrm{GHz}$. The method is based on measurements of resonant frequency and quality factor of the empty resonator, the resonator with the substrate $\left(\mathrm{Al}_{2} \mathrm{O}_{3}\right)$, and finally the resonator with dielectric deposited on top of the substrate (in this case $\mathrm{TiTe}_{3} \mathrm{O}_{8}$ on $\mathrm{Al}_{2} \mathrm{O}_{3}$ ) with the same exact dimensions and shape. The dielectric parameters of the measured thick dielectric films are calculated based on full-wave electromagnetic analysis.

\section{Results}

Before alumina substrates are used for EPD, the essential step is to sputter a carbon layer upon it to make them conductive, as explained before. The carbon coatings certainly 
affect the EPD process and thereby the quality of $\mathrm{TiTe}_{3} \mathrm{O}_{8}$ films and their final dielectric performance. According to our previous results, there is an optimum carbon layer thickness in the range between 200 and $400 \mathrm{~nm}$ that guarantees a continuous uniform high quality film deposition [13]. Carbon layers with thickness below $100 \mathrm{~nm}$ cannot be used as temporary electrodes for EPD since the formed layer is not sufficiently conductive to permit the deposition of a continuous film. On the other hand, with too thick ( $>500 \mathrm{~nm}$ ) carbon layers, non-conformal and non-uniform films are obtained after sintering, because thick carbon layers restrict the final film adhesion to the substrate. Therefore, $\sim 300 \mathrm{~nm}$ thick carbon layer was selected to be used in the present work.

The surface of the green (non-sintered) $\mathrm{TiTe}_{3} \mathrm{O}_{8}$ thick films deposited by EPD under $100 \mathrm{~V}$ for $3 \mathrm{~min}$ on carbon coated alumina substrate is presented in Figure 1a. Very uniform and crack free $\mathrm{TiTe}_{3} \mathrm{O}_{8}$ film with circular shape is seen on the background of the black carbon layer with square shape. The cross-section microstructure of these green films is illustrated in Figure 1 b,d. The low magnification SEM micrograph depicts a very uniform, compact and conformal $\sim 50 \mu \mathrm{m}$ thick $\mathrm{TiTe}_{3} \mathrm{O}_{8}$ film on the carbon coated alumina substrate (Figure $1 \mathrm{~b}, \mathrm{c}$ ). $\mathrm{TiTe}_{3} \mathrm{O}_{8}$ particles are densely packed and deposited on the substrate thanks to the carbon coating conductive surface. The uniform continuous conformal carbon layer with thickness of $\sim 300 \mathrm{~nm}$ can be easily observed from the high magnification micrographs (Figure 1c,d).

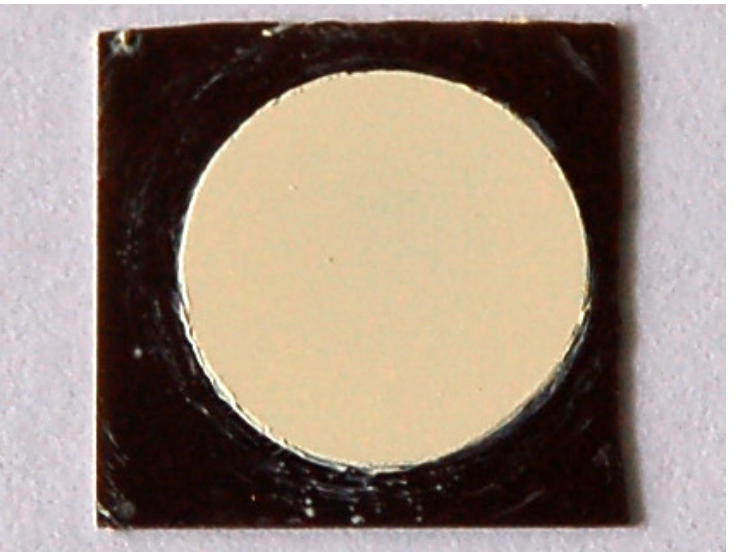

(a)

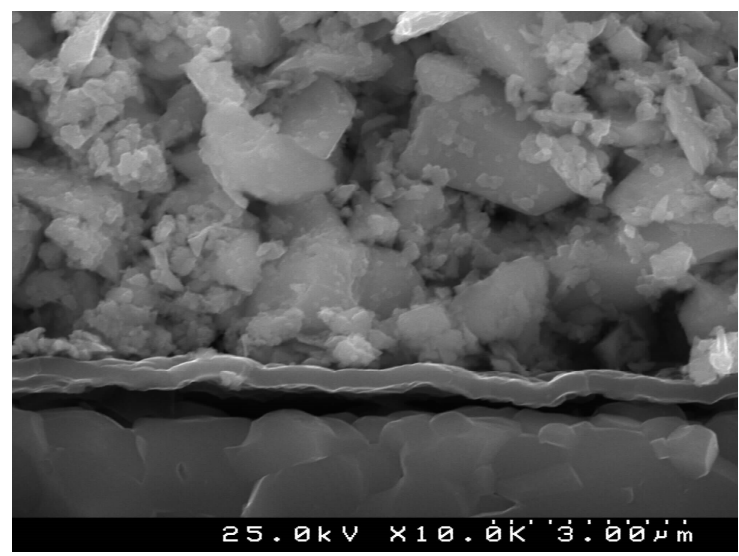

(c)

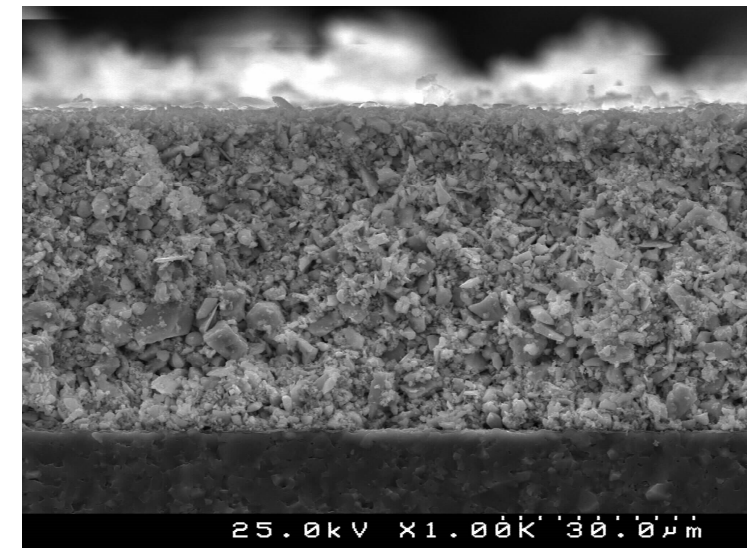

(b)

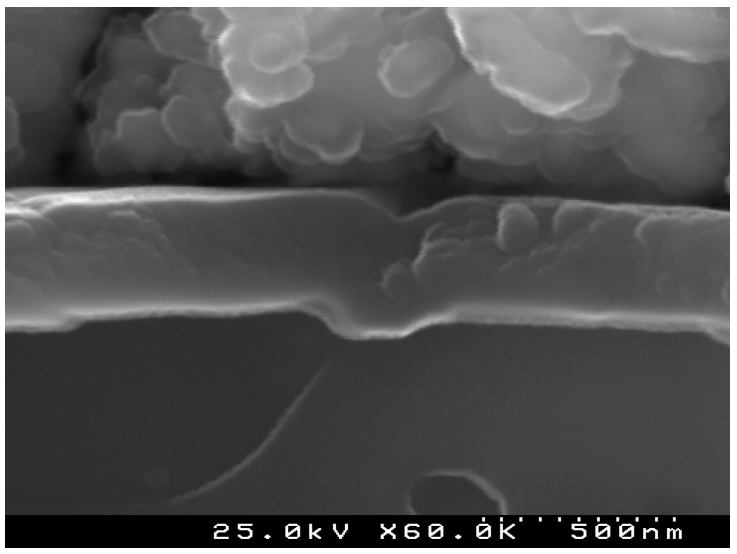

(d)

Figure 1. A surface optical image (a) and cross section SEM micrographs (b-d) of a green $\mathrm{TiTe}_{3} \mathrm{O}_{8}$ thick film deposited by EPD under $100 \mathrm{~V}$ for $3 \mathrm{~min}$ on carbon coated $25.4 \times 25.4 \times 0.0254 \mathrm{~mm}^{3}$ alumina substrate: very uniform and crack free $\mathrm{TiTe}_{3} \mathrm{O}_{8}$ film with a circular shape on a background of a black carbon layer (a), average film thickness of $\sim 50 \mu \mathrm{m}$ (b) and compact microstructure of the film (c) on a continuous $\sim 300 \mathrm{~nm}$ carbon layer (d) are visible. 
The optical images of $\mathrm{TiTe}_{3} \mathrm{O}_{8}$ films deposited on carbon coated alumina substrates sintered for $5 \mathrm{~h}$ in air at 680 (a), 700 (b) and $720{ }^{\circ} \mathrm{C}$ (c), respectively, are presented in Figure 2. Sintered $\mathrm{TiTe}_{3} \mathrm{O}_{8}$ films exhibit the yellow colour characteristic of polycrystalline $\mathrm{TiTe}_{3} \mathrm{O}_{8}$ and the alumina substrates present the original white colour. For films sintered at $680{ }^{\circ} \mathrm{C}$ (Figure 2a), the substrate is slightly darker than for the other sintered films. This is possibly due to an incomplete burn out of the sacrificial carbon layer, although thermal analysis (see Appendix A Figure A1) clearly indicates that the carbon layer oxidizes in air below $660{ }^{\circ} \mathrm{C}$ and thus below the sintering temperature of $\mathrm{TiTe}_{3} \mathrm{O}_{8}$ films. After sintering at $680{ }^{\circ} \mathrm{C}$, films still present a powder-like aspect, similar to the green ones, and do not have good adhesion to the alumina substrates, being easily detached. Therefore, under the present conditions, the sintering temperature of $680{ }^{\circ} \mathrm{C}$ is not enough to fully densify $\mathrm{TiTe}_{3} \mathrm{O}_{8}$ thick films on $\mathrm{Al}_{2} \mathrm{O}_{3}$.

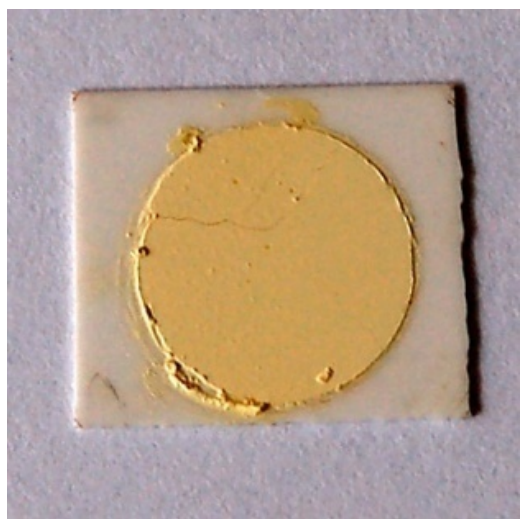

(a)

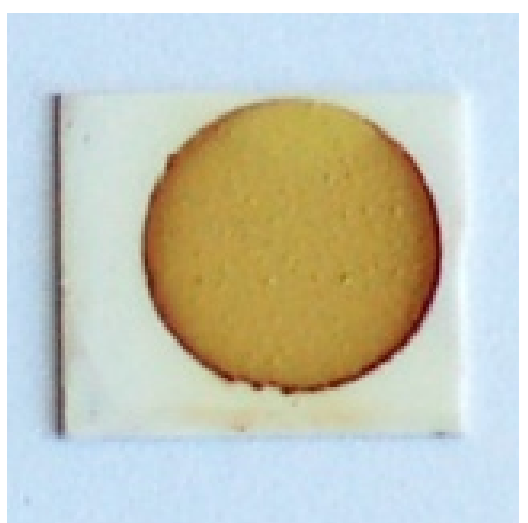

(b)

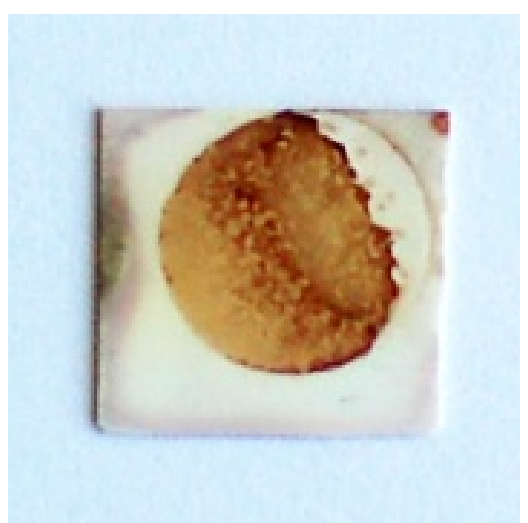

(c)

Figure 2. Optical images of $\mathrm{TiTe}_{3} \mathrm{O}_{8}$ films deposited on carbon coated $25.4 \times 25.4 \times 0.0254 \mathrm{~mm}^{3}$ alumina substrates and sintered at $680(\mathbf{a}), 700(\mathbf{b})$ and $720^{\circ} \mathrm{C}(\mathbf{c})$ for $5 \mathrm{~h}$, respectively. Films sintered at $680{ }^{\circ} \mathrm{C}$ are not fully dense and some films sintered at $720^{\circ} \mathrm{C}$ exhibit an irregular surface with a reddish colour resulting from a reaction with the alumina substrate.

Films sintered at higher temperatures, $700^{\circ} \mathrm{C}$ and $720^{\circ} \mathrm{C}$, are denser and do not detach from the substrate. However, films sintered at $720^{\circ} \mathrm{C}$ exhibit areas with an irregular surface and a reddish colour, as seen from Figure $2 c$. For films sintered at $700{ }^{\circ} \mathrm{C}$, (Figure $2 \mathrm{~b}$ ) only some reddish vestiges at the edges may be seen. This reddish colour, not observed for the films sintered at $680{ }^{\circ} \mathrm{C}$, may be indicative of some reaction with the alumina substrate. Indeed, in our previous work [33] we proposed that the formation of 1:1 stoichiometry binary $\mathrm{Al}_{2} \mathrm{O}_{3}-\mathrm{TeO}_{2}$ compound results from the oxidation of $\mathrm{TeO}_{2}$, which occurs at temperatures > $600{ }^{\circ} \mathrm{C}$ to form $\mathrm{Te}_{4} \mathrm{O}_{9}$ and $\mathrm{TeO}_{3}$, that triggers the formation of $\mathrm{Al}_{2} \mathrm{TeO}_{6}$. Under vacuum the oxidation of $\mathrm{TeO}_{2}$ does not take place and there is no reaction between $\mathrm{Al}_{2} \mathrm{O}_{3}$ and $\mathrm{TeO}_{2}$.

To understand what gives rise to these observations and to support our predictions we conducted XRD analysis to examine the evolution of the formed phases under different sintering conditions (Figure 3). For the sintering temperature of $680^{\circ} \mathrm{C}$, the XRD pattern reveals only peaks of $\mathrm{TiTe}_{3} \mathrm{O}_{8}$ phase (JCPDS 70-2439) identical to those of calcined powders [30]. However, as hypothesised, for films sintered at $700{ }^{\circ} \mathrm{C}$ and $720{ }^{\circ} \mathrm{C}$, a new phase of $\mathrm{Al}_{2} \mathrm{TeO}_{6}$ (JCPDS 15-0689) can be identified. For films sintered at $700{ }^{\circ} \mathrm{C}, \mathrm{Al}_{2} \mathrm{TeO}_{6}$ is residual, but for films sintered at $720{ }^{\circ} \mathrm{C}, \mathrm{Al}_{2} \mathrm{TeO}_{6}$ is clearly visible and even peaks of $\mathrm{TiO}_{2}$ can be detected, indicative of $\mathrm{TiTe}_{3} \mathrm{O}_{8}$ decomposition. Thus, the reddish colour observed in $\mathrm{TiTe}_{3} \mathrm{O}_{8}$ thick films sintered at temperatures higher than $700{ }^{\circ} \mathrm{C}$ is related to the formation $\mathrm{Al}_{2} \mathrm{TeO}_{6}$ phase, which results from the reaction between $\mathrm{TeO}_{2}$ from $\mathrm{TiTe}_{3} \mathrm{O}_{8}$ and alumina substrates. 


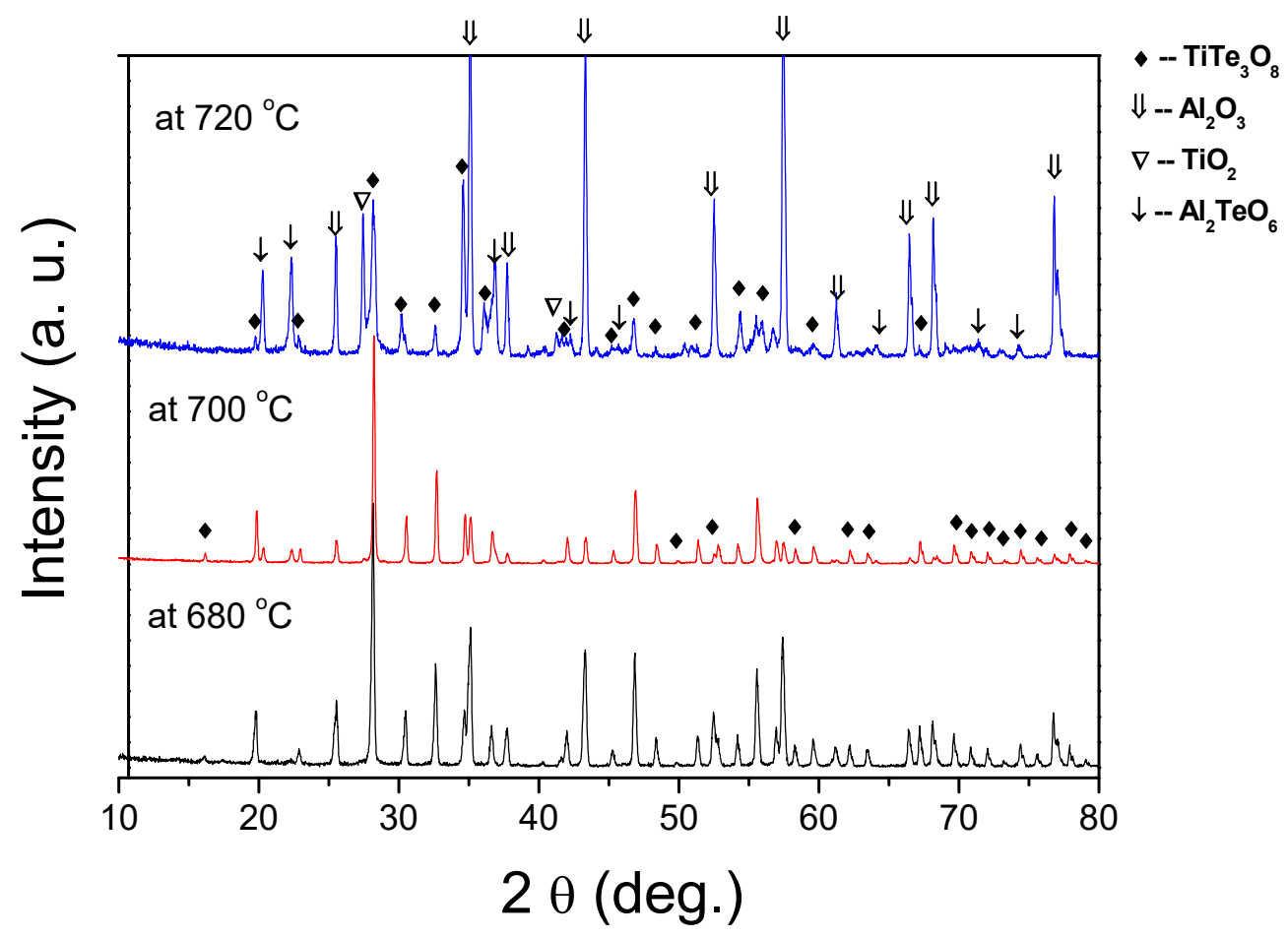

Figure 3. XRD patterns of $\mathrm{TiTe}_{3} \mathrm{O}_{8}$ films deposited on carbon coated alumina substrates and sintered at 680,700 and $720{ }^{\circ} \mathrm{C}$ for $5 \mathrm{~h}$. The main film's phase is $\mathrm{TiTe}_{3} \mathrm{O}_{8}$. For films sintered above $700{ }^{\circ} \mathrm{C}$ $\mathrm{Al}_{2} \mathrm{TeO}_{6}$ is formed due to a reaction between $\mathrm{TeO}_{2}$ and $\mathrm{Al}_{2} \mathrm{O}_{3}$ substrates.

We have also inspected the microstructure of the sintered $\mathrm{TiTe}_{3} \mathrm{O}_{8}$ films deposited on carbon coated alumina substrates, for the films sintered at $700{ }^{\circ} \mathrm{C}$ for $5 \mathrm{~h}$ (Figure 4). Films present a uniform and dense surface microstructure with the typical cubic shaped grains of $\mathrm{TiTe}_{3} \mathrm{O}_{8}$ and well visible grain boundaries (Figure 4a). In agreement, a dense microstructure (with only some residual porosity), a thickness of $\sim 19 \mu \mathrm{m}$ as well as a good adhesion to the substrate can be observed from the cross-section SEM micrographs (Figure $4 \mathrm{~b}$ ). There is also a thin reaction layer between the film and the substrate interface with a thickness of $<200 \mathrm{~nm}$ (Figure 4c).

EDS was used for the analysis of the interface between $\mathrm{TiTe}_{3} \mathrm{O}_{8}$ films and $\mathrm{Al}_{2} \mathrm{O}_{3}$ substrates (Figure $4 \mathrm{c}$ ). The interlayer at the interface between the film and the substrate (region $\mathrm{A}$ ) is $\mathrm{Al}$ and $\mathrm{Te}$ rich, indicating the presence of $\mathrm{Al}_{2} \mathrm{TeO}_{6}$ and confirming the previous XRD data. On the other hand, for region $\mathrm{B}$, which corresponds to the main bulk of the thick film, the detected elements are mainly $\mathrm{Te}$ and $\mathrm{Ti}$, from $\mathrm{TiTe}_{3} \mathrm{O}_{8}$, being the peak for $\mathrm{Al}$ considerably low. Thus, under the sintering conditions of $700{ }^{\circ} \mathrm{C}$ for $5 \mathrm{~h}$ in air rather dense $19-\mu \mathrm{m}$-thick $\mathrm{TiTe}_{3} \mathrm{O}_{8}$ films are prepared with the presence of a thin $(<200 \mathrm{~nm})$ reaction interlayer of $\mathrm{Al}_{2} \mathrm{TeO}_{6}$.

The dielectric properties of two most homogeneous and single phase $\mathrm{TiTe}_{3} \mathrm{O}_{8}$ thick films on $\mathrm{Al}_{2} \mathrm{O}_{3}$ substrates analysed by SPDR method at $20 \mathrm{GHz}$ are presented in Table 1 . 21- $\mu$ m-thick $\mathrm{TiTe}_{3} \mathrm{O}_{8}$ films sintered at $680{ }^{\circ} \mathrm{C}$ for $5 \mathrm{~h}$ display a $\varepsilon_{\mathrm{r}}$ value of 28 and a $\mathrm{Q} \times \mathrm{f}$ value of 21,978 , while $19-\mu \mathrm{m}$-thick films sintered at $700{ }^{\circ} \mathrm{C}$ for $5 \mathrm{~h}$ display $\varepsilon_{\mathrm{r}}$ of 32 and $\mathrm{Q} \times \mathrm{f}$ of 21,053 . Thus, relative permittivity of $\mathrm{TiTe}_{3} \mathrm{O}_{8}$ thick films varies between 28 and 32 and $\mathrm{Q} \times \mathrm{f}$ varies approximately between 21,000 and 22,000. This uncertainty reflects the differences in the density, thickness and possibly the residual presence of the interfacial reaction with $\mathrm{Al}_{2} \mathrm{O}_{3}$. Indeed, the dielectric permittivity of the $\mathrm{Al}_{2} \mathrm{TeO}_{6}$ interface layer present in films sintered at $700{ }^{\circ} \mathrm{C}$ is smaller than that of $\mathrm{TiTe}_{3} \mathrm{O}_{8}$ [33]. In a series connection, this should deteriorate the total dielectric properties. However, the negative effect that may be induced by a $<200 \mathrm{~nm}$-thick interface layer is apparently compensated by higher density of the films sintered at $700{ }^{\circ} \mathrm{C}$ comparing to that of the films sintered at $680^{\circ} \mathrm{C}$ 


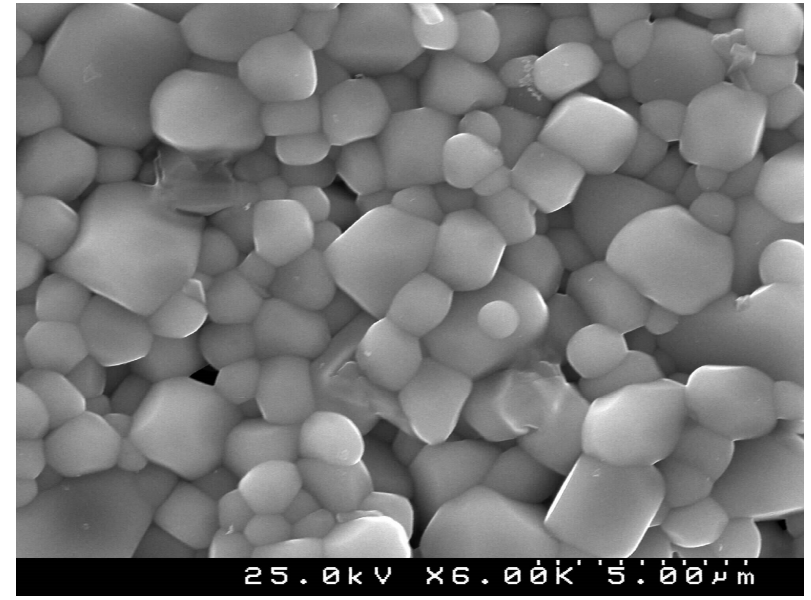

(a)

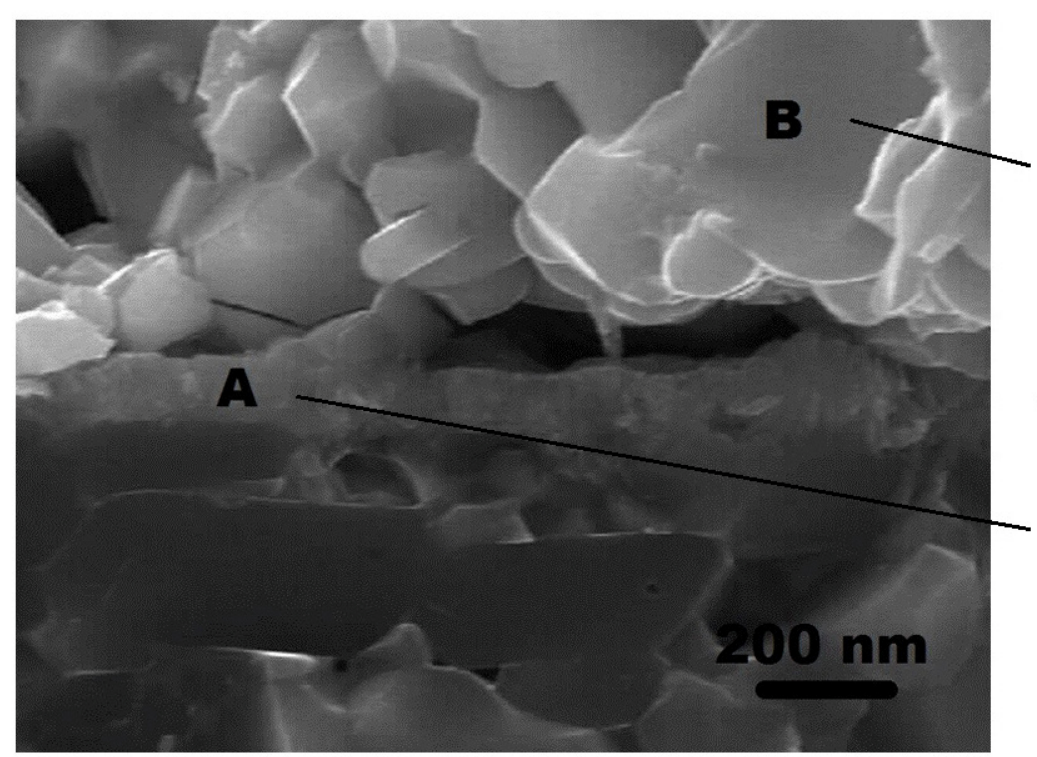

(c)

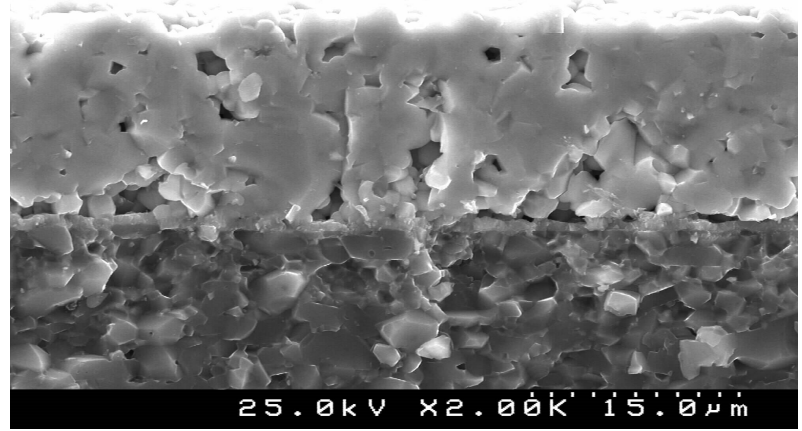

(b)

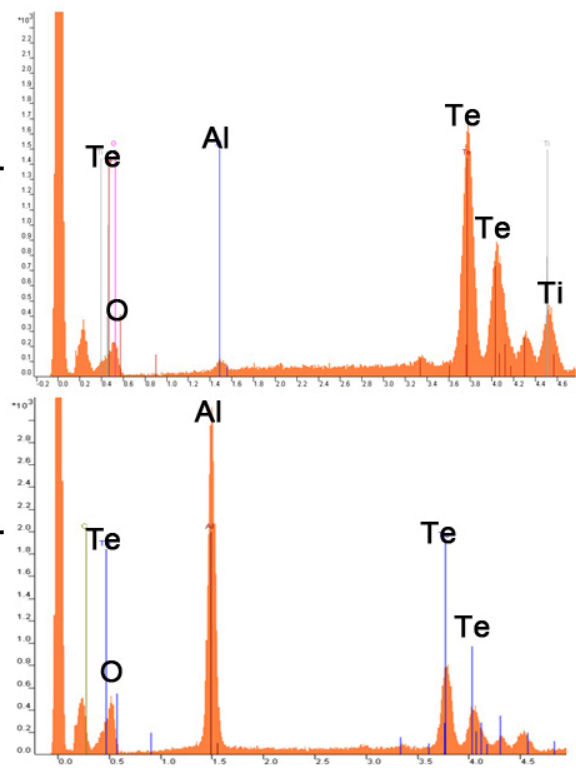

$\mathrm{Ti}$

Figure 4. SEM micrographs of $\mathrm{TiTe}_{3} \mathrm{O}_{8}$ films deposited on carbon coated alumina substrates sintered at $700{ }^{\circ} \mathrm{C}$ for $5 \mathrm{~h}$, surface (a), cross section (b) and high magnification cross section and energy dispersive spectra for indicated locations (c). Under these sintering conditions $\left(700{ }^{\circ} \mathrm{C}\right.$ for $5 \mathrm{~h}$ in air) $\mathrm{TiTe}_{3} \mathrm{O}_{8}$ films are dense and uniform with the presence of a thin $(<200 \mathrm{~nm})$ reaction interlayer of $\mathrm{Al}_{2} \mathrm{TeO}_{6}$ confined to the interface between the film and the substrate.

The dielectric performance of $\mathrm{TiTe}_{3} \mathrm{O}_{8}$ films on $\mathrm{Al}_{2} \mathrm{O}_{3}$ substrates summarized in Table 1 is also compared to that reported for corresponding ceramics at high $(\mathrm{GHz})$ frequencies. It is worthwhile to mention that $\mathrm{Q} \times \mathrm{f}$ for $\mathrm{TiTe}_{3} \mathrm{O}_{8}$ thick films have not been reported so far. $\varepsilon_{\mathrm{r}}$ of 50 and $\mathrm{Q} \times \mathrm{f}$ of $30,600 \mathrm{GHz}$ at $5 \mathrm{GHz}$ were reported for $\mathrm{TiTe}_{3} \mathrm{O}_{8}$ ceramics sintered at $720{ }^{\circ} \mathrm{C}$ [15]. Besides the lower measurement frequency, the observed differences of the dielectric behaviour between $\mathrm{TiTe}_{3} \mathrm{O}_{8}$ thick films and ceramics might also be related to density, residual presence of $\mathrm{Al}_{2} \mathrm{TeO}_{6}$ secondary phase and details of the microstructure. For other $\mathrm{TiTe}_{3} \mathrm{O}_{8}$ ceramics, sintered at $700{ }^{\circ} \mathrm{C} / 5 \mathrm{~h}, \varepsilon_{\mathrm{r}}$ and $\mathrm{Q}$ at $4 \mathrm{GHz}$ were reported to be 36 and 3400, respectively [14]. Comparing these $\mathrm{TiTe}_{3} \mathrm{O}_{8}$ ceramics with our films on $\mathrm{Al}_{2} \mathrm{O}_{3}$, the results here obtained are rather promising. Moreover, the low losses of polycrystalline alumina $\left(\varepsilon_{\mathrm{r}}=9, \tan \delta=9.46 \times 10^{-5}, \mathrm{Q}=10570\right.$-for $>99 \%$ pure $\left.\mathrm{Al}_{2} \mathrm{O}_{3}\right)$ [34] should improve the dielectric performance of the final device $\mathrm{TiTe}_{3} \mathrm{O}_{8} / \mathrm{Al}_{2} \mathrm{O}_{3}$ composite structure. 
Table 1. Relative dielectric permittivity, quality factor-frequency product and losses of $\mathrm{TiTe}_{3} \mathrm{O}_{8}$ thick films and ceramics. Sintering conditions are also indicated.

\begin{tabular}{cccccc}
\hline \multicolumn{1}{c}{$\mathrm{TiTe}_{3} \mathrm{O}_{\mathbf{8}}$} & \multicolumn{3}{c}{ Dielectric Properties } \\
\hline Type & $\begin{array}{c}\text { Sintering } \\
\text { Conditions }\end{array}$ & $\begin{array}{c}\text { Measurement } \\
\text { Frequency, GHz }\end{array}$ & $\mathbf{E}_{\mathbf{r}}$ & $\mathbf{Q} \times \mathbf{f}, \mathbf{G H z}$ & Ref. \\
\hline $21-\mu \mathrm{m}$-thick $\mathrm{TiTe}_{3} \mathrm{O}_{8}$ films on $\mathrm{Al}_{2} \mathrm{O}_{3}$ & $680^{\circ} \mathrm{C} / 5 \mathrm{~h}$ & 20 & 28 & 21,978 & This work \\
$19-\mu \mathrm{m}$ thick $\mathrm{TiTe}_{3} \mathrm{O}_{8}$ films on $\mathrm{Al}_{2} \mathrm{O}_{3}$ & $700^{\circ} \mathrm{C} / 5 \mathrm{~h}$ & 20 & 32 & 21,053 & This work \\
$\mathrm{TiTe}_{3} \mathrm{O}_{8}$ ceramics & $700^{\circ} \mathrm{C} / 5 \mathrm{~h}$ & 4 & 36 & 13,600 & {$[14]$} \\
$\mathrm{TiTe}_{3} \mathrm{O}_{8}$ ceramics & $720^{\circ} \mathrm{C}$ & 5 & 50 & 30,600 & {$[15]$} \\
\hline
\end{tabular}

Overall and by comparison, EPD TiTe ${ }_{3} \mathrm{O}_{8}$ thick films on $\mathrm{Al}_{2} \mathrm{O}_{3}$ reveal a high performance in terms of permittivity and loss tangent (high $\mathrm{Q}$ features) making them promising low-sintering-temperature dielectrics for micron sized high-frequency devices.

\section{Conclusions}

We have fabricated low-loss (high-Q) $\mathrm{TiTe}_{3} \mathrm{O}_{8}$ thick films directly on $\mathrm{Al}_{2} \mathrm{O}_{3}$ substrates by EPD and reported for the first time their microwave dielectric properties. Nineteen micrometre-thick $\mathrm{TiTe}_{3} \mathrm{O}_{8}$ films on $\mathrm{Al}_{2} \mathrm{O}_{3}$ sintered at $700{ }^{\circ} \mathrm{C}$ have the relative permittivity of 32 and $\mathrm{Q} \times \mathrm{f}>21,000 \mathrm{GHz}$ at a frequency of $20 \mathrm{GHz}$. Our results confirm the crucial role of a sacrificial carbon conductive coating on non-conductive $\mathrm{Al}_{2} \mathrm{O}_{3}$ substrate for the direct utilization of insulating substrates in EPD. During the sintering of $\mathrm{TiTe}_{3} \mathrm{O}_{8}$ films on $\mathrm{Al}_{2} \mathrm{O}_{3}$ at temperatures above $700{ }^{\circ} \mathrm{C}$, an interfacial reaction between $\mathrm{Al}_{2} \mathrm{O}_{3}$ and $\mathrm{TiTe}_{3} \mathrm{O}_{8}$ takes place resulting in the formation of a stable aluminium tellurite compound, $\mathrm{Al}_{2} \mathrm{TeO}_{6}$. However, our findings also suggest that this thin (100-200 nm) interlayer of low-loss aluminium tellurite has no significant negative effect on the final properties of $\mathrm{TiTe}_{3} \mathrm{O}_{8}$ films. Finally, our results provide relevant information for the use of $\mathrm{TiTe}_{3} \mathrm{O}_{8}$ thick films on $\mathrm{Al}_{2} \mathrm{O}_{3}$ substrates as microlayer microstrip arrays in antennas, filters and transceivers for microwave telecommunications, satellite broadcasting and intelligent transport systems.

Author Contributions: Conceptualization, P.M.V.; investigation, X.S., A.T. and J.K.; methodology, X.S., A.T., J.K. and P.M.V.; writing-original draft preparation, P.M.V.; writing-review and editing, A.T. and P.M.V.; supervision, P.M.V. All authors have read and agreed to the published version of the manuscript.

Funding: This work was developed within the scope of the project CICECO-Aveiro Institute of Materials, UIDB/50011/2020 and UIDP/50011/2020, financed by national funds through the Portuguese Foundation for Science and Technology/MCTES.

Institutional Review Board Statement: Not applicable.

Informed Consent Statement: Not applicable.

Data Availability Statement: The data presented in this study are available on request from the corresponding author.

Conflicts of Interest: The authors declare no conflict of interest. 


\section{Appendix A}

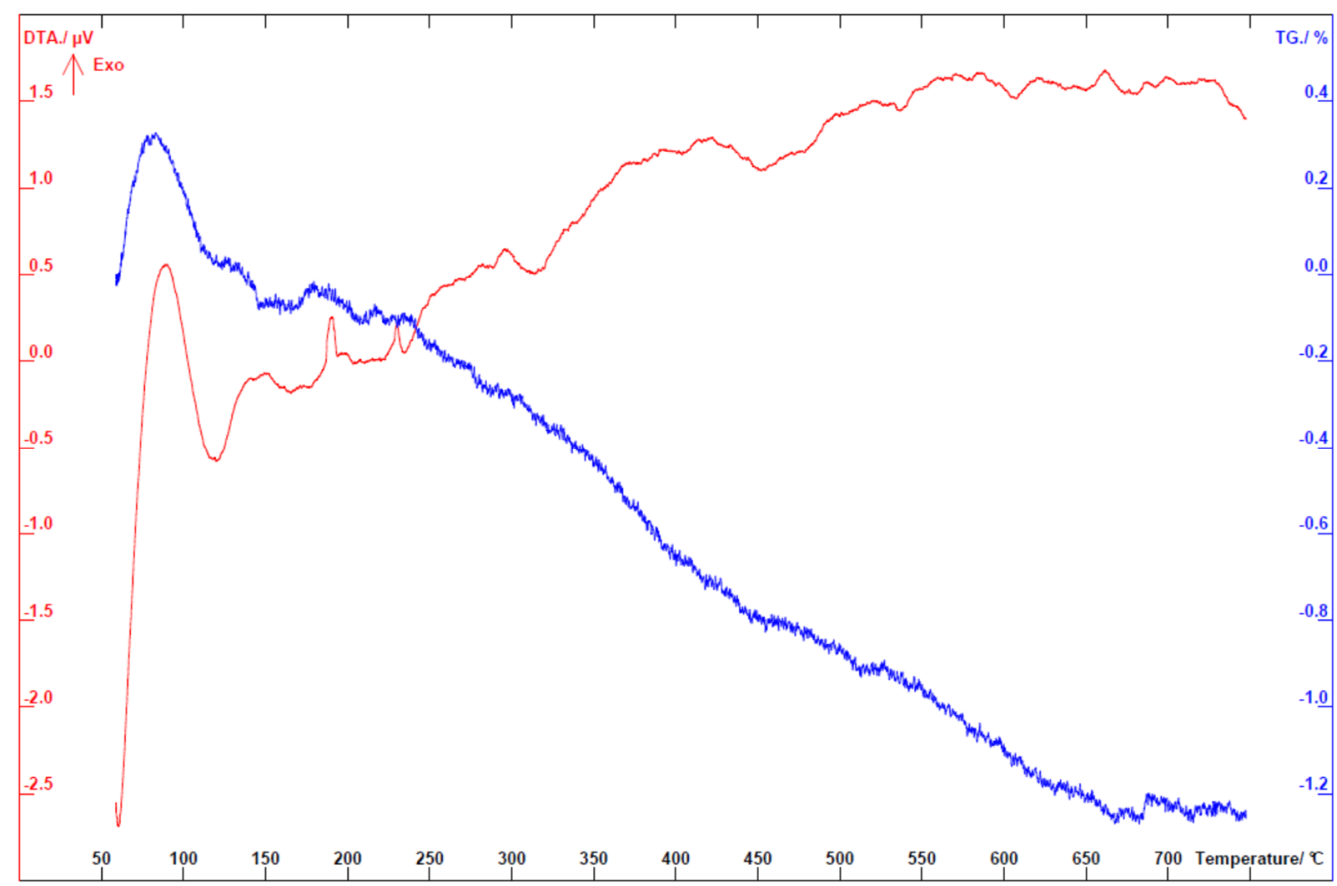

Figure A1. Differential thermal analysis (DTA) and thermogravimetric (TG) analysis curves recorded in air on graphite coated $\mathrm{Al}_{2} \mathrm{O}_{3}$ substrate.

\section{References}

1. Reaney, I.M.; Iddles, D. Microwave Dielectric Ceramics for Resonators and Filters in Mobile Phone Networks. J. Am. Ceram. Soc. 2006, 89, 2063-2072. [CrossRef]

2. Scott, A.W. Understanding Microwaves; Wiley: New York, NY, USA, 1993.

3. Vilarinho, P.M.; Fu, Z.; Kingon, A.I.; Tkach, A. Low loss tunable dielectric $\mathrm{BaNd}_{2} \mathrm{Ti}_{5} \mathrm{O}_{14}-\left(\mathrm{Ba}_{0.5} \mathrm{Sr}_{0.5}\right) \mathrm{TiO}_{3}$ composite thick films. Scr. Mater. 2018, 155, 160-163. [CrossRef]

4. Stephens, D.; Young, P.; Robertson, I. Millimeter-wave substrate integrated waveguides and filters in photoimageable thick-film technology. IEEE Trans. Microw. Theory Tech. 2005, 53, 3832-3838. [CrossRef]

5. Samanta, K.K. Advanced multilayer thick-film technology and TFMS, CPW, and SIW up to $180 \mathrm{GHz}$ for cost-effective ceramicbased circuits and modules. IET Microw. Antennas Propag. 2018, 12, 1064-1071. [CrossRef]

6. Sarkar, P.; Nicholson, P.S. Electrophoretic Deposition (EPD): Mechanisms, Kinetics, and Application to Ceramics. J. Am. Ceram. Soc. 1996, 79, 1987-2002. [CrossRef]

7. Zhitomirsky, I. Cathodic electrodeposition of ceramic and organoceramic materials. Fundamental aspects. Adv. Colloid Interface Sci. 2002, 97, 279-317. [CrossRef]

8. Besra, L.; Liu, M. A review on fundamentals and applications of electrophoretic deposition (EPD). Prog. Mater. Sci. 2007, 52, 1-61. [CrossRef]

9. Corni, I.; Ryan, M.P.; Boccaccini, A.R. Electrophoretic deposition: From traditional ceramics to nanotechnology. J. Eur. Ceram. Soc. 2008, 28, 1353-1367. [CrossRef]

10. Lee, S.H.; Woo, S.P.; Kakati, N.; Kim, D.-J.; Yoon, Y.S. A Comprehensive Review of Nanomaterials Developed Using Electrophoresis Process for High-Efficiency Energy Conversion and Storage Systems. Energies 2018, 11, 3122. [CrossRef]

11. Basu, R.N.; Randall, C.A.; Mayo, M.J. Fabrication of Dense Zirconia Electrolyte Films for Tubular Solid Oxide Fuel Cells by Electrophoretic Deposition. J. Am. Ceram. Soc. 2001, 84, 33-40. [CrossRef]

12. Hosomi, T.; Matsuda, M.; Miyake, M. Electrophoretic deposition for fabrication of YSZ electrolyte film on non-conducting porous NiO-YSZ composite substrate for intermediate temperature SOFC. J. Eur. Ceram. Soc. 2007, 27, 173-178. [CrossRef]

13. Vilarinho, P.M.; Fu, Z.; Wu, A.; Axelsson, A.; Kingon, A.I. Electrophoretic Deposition on Nonconducting Substrates: A Demonstration of the Application to Microwave Devices. Langmuir 2015, 31, 2127-2135. [CrossRef]

14. Maeda, M.; Yamamura, T.; Ikeda, T. Dielectric Characteristics of Several Complex Oxide Ceramics at Microwave Frequencies. Jpn. J. Appl. Phys. 1987, 26, 76-79. [CrossRef]

15. Udovic, M.; Valant, M.; Suvorov, D. Dielectric characterisation of ceramics from the $\mathrm{TiO}_{2}-\mathrm{TeO}_{2}$ system. J. Eur. Ceram. Soc. 2001, 21, 1735-1738. [CrossRef] 
16. Udovic, M.; Valant, M.; Suvorov, D. Phase Formation and Dielectric Characterization of the $\mathrm{Bi}_{2} \mathrm{O}_{3}-\mathrm{TeO}_{2}$ System Prepared in an Oxygen Atmosphere. J. Am. Ceram. Soc. 2004, 87, 591-597. [CrossRef]

17. Valant, M.; Suvorov, D. Glass-free low-temperature cofired ceramics: Calcium germanates, silicates and tellurates. J. Eur. Ceram. Soc. 2004, 24, 1715-1719. [CrossRef]

18. Kwon, D.-K.; Lanagan, M.T.; Shrout, T.R. Synthesis of BaTiTe ${ }_{3} \mathrm{O}_{9}$ Ceramics for LTCC Application and Its Dielectric Properties. J Ceram. Soc. Jpn. 2005, 113, 216-219. [CrossRef]

19. Kwon, D.-K.; Lanagan, M.T.; Shrout, T.R. Microwave Dielectric Properties and Low-Temperature Cofiring of BaTe $\mathrm{O}_{9}$ with Aluminum Metal Electrode. J. Am. Ceram. Soc. 2005, 88, 3419-3422. [CrossRef]

20. Udovic, M.; Valant, M.; Jančar, B.; Suvorov, D.; Meden, A.; Kočevar, A. Phase Formation and Crystal-Structure Determination in the $\mathrm{Bi}_{2} \mathrm{O}_{3}-\mathrm{TiO}_{2}-\mathrm{TeO}_{2}$ System Prepared in an Oxygen Atmosphere. J. Am. Ceram. Soc. 2006, 89, 3462-3469. [CrossRef]

21. Udovic, M.; Suvorov, D. Sintering and Dielectric Characterization of Pseudoternary Compounds from the $\mathrm{Bi}_{2} \mathrm{O}_{3}-\mathrm{TiO}_{2}-\mathrm{TeO}_{2}$ System. J. Am. Ceram. Soc. 2007, 90, 2404-2408. [CrossRef]

22. Kwon, D.-K.; Lanagan, M.T.; Shrout, T.R. Microwave dielectric properties of $\mathrm{BaO}_{-} \mathrm{TeO}_{2}$ binary compounds. Mater. Lett. 2007, 61, 1827-1831. [CrossRef]

23. Subodh, G.; Sebastian, M.T. Glass-Free $\mathrm{Zn}_{2} \mathrm{Te}_{3} \mathrm{O}_{8}$ Microwave Ceramic for LTCC Applications. J. Am. Ceram. Soc. 2007, 90, 2266-2268. [CrossRef]

24. Subodh, G.; Sebastian, M.T. Microwave Dielectric Properties of $\mathrm{ATe}_{3} \mathrm{O}_{8}(\mathrm{~A}=\mathrm{Sn}, \mathrm{Zr})$ Ceramics. Jpn. J. Appl. Phys. 2008, 47, 7943-7946. [CrossRef]

25. Subodh, G.; Ratheesh, R.; Jacob, M.; Sebastian, M. Microwave dielectric properties and vibrational spectroscopic analysis of $\mathrm{MgTe}_{2} \mathrm{O}_{5}$ ceramics. J. Mater. Res. 2008, 23, 1551-1556. [CrossRef]

26. Wang, S.-F.; Wang, Y.-R.; Hsu, Y.-F.; Tsai, J.-S. Densification, microstructure and microwave dielectric properties of ultra-low fire $\mathrm{BaTe}_{4} \mathrm{O}_{9}-\mathrm{TiTe}_{3} \mathrm{O}_{8}$ ceramic composites. J. Eur. Ceram. Soc. 2010, 30, 1737-1741. [CrossRef]

27. Jiao, X.; Zhong, C.; Zhang, S.; Liu, X.; Li, B. Microwave dielectric properties of $\mathrm{BaO}-\mathrm{TiO}_{2}-\mathrm{TeO}_{2}$ ternary system. J. Mater. Sci. 2010, 45, 3331-3335. [CrossRef]

28. Kagomiya, I.; Kodama, Y.; Shimizu, Y.; Kakimoto, K.-I.; Ohsato, H.; Miyauchi, Y. Low-temperature sintering and microwave dielectric properties of $\mathrm{Al}_{2} \mathrm{TeO}_{6}-\mathrm{TeO}_{2}$ ceramics. J. Alloy. Compd. 2015, 640, 383-387. [CrossRef]

29. Sebastian, M.T.; Wang, H.; Jantunen, H. Low temperature co-fired ceramics with ultra-low sintering temperature: A review. Curr. Opin. Solid State Mater. Sci. 2016, 20, 151-170. [CrossRef]

30. Su, X.; $\mathrm{Wu}, \mathrm{A}$.; Vilarinho, P.M. Titanium tellurite thick films prepared by electrophoretic deposition and their dielectric properties. Scr. Mater. 2009, 61, 536-539. [CrossRef]

31. Su, X.; Wu, A.; Vilarinho, P.M. Triethanolamine as an Additive in the Electrophoretic Deposition of $\mathrm{TiTe}_{3} \mathrm{O}_{8} \mathrm{Thick}$ Films. Key Eng. Mater. 2012, 507, 27-34. [CrossRef]

32. Krupka, J. Microwave Measurements of Electromagnetic Properties of Materials. Materials 2021, 14, 5097. [CrossRef] [PubMed]

33. $\mathrm{Su}, \mathrm{X} . ; \mathrm{Wu}, \mathrm{A} . ;$ Vilarinho, P.M. $\mathrm{Al}_{2} \mathrm{TeO}_{6}$ : Mechanism of phase formation and dielectric properties. Scr. Mater. 2012, 67, 927-930. [CrossRef]

34. Thorp, J.S.; Akhtaruzzaman, M.; Evans, D. The dielectric properties of alumina substrates for microelectronic packaging. J. Mater Sci. 1990, 25, 4143-4149. [CrossRef] 